\title{
Most prevalent symptoms associated with headache in COVID-19 patients in the acute phase: a systematic review
}

\author{
Vitória Rodrigues Salomão1 (D) , Anna Júlia Romão Baccarin² (D) , Thaís Yayoi Okido ${ }^{3}$ \\ Pontifícia Universidade Católica do Paraná, Campus Londrina (PUC-PR), Londrina, Brazil.
}

$\bigotimes$

Vitória Rodrigues Salomão

Rua Anu Branco, 366,

Jardim Portal das Flores, CEP: 86701-530Arapongas, PR, Brasil vitoria_salomao@hotmail.com

Edited by

Marcelo Moraes Valença

Keywords:

Headache

COVID-19

Coronavirus

Nervous system diseases

Anosmia

Ageusia

\begin{abstract}
Introduction

Considering the frequency of headache among the neurological symptoms of COVID-19, there is a need to understand other manifestations associated with this complaint. Objective

To review the literature regarding the most prevalent symptoms associated with headache in patients diagnosed with COVID-19.

Method

A systematic literature review was carried out on studies that evaluated published articles about clinical characteristics and headache associated symptoms in patients diagnosed with COVID-19.

Results

Among the 1,190 patients in the analyzed studies, the following signs and symptoms were associated with headache: fever, hyposmia, anosmia, ageusia, phonophobia, dehydration, prostration and symptoms of the gastrointestinal tract.

Conclusion

Headache was the main neurological symptom of COVID-19, among the main associated symptoms are fever, hyposmia or anosmia, ageusia and phonophobia.
\end{abstract}




\section{Introduction}

n December 2019, in Wuhan, Hubei province, China, a new disease caused by the coronavirus was identified, named COVID-19, referring to "Coronavirus disease 2019". With its high transmissibility, the WHO announced COVID-19 as a pandemic in March 2020. The virus responsible for severe acute respiratory syndrome 2 (SARS-CoV-2) has a single RNA envelope and strand structure and belongs to the B-Coronaviruse Family. ${ }^{1}$

The highly contagious disease has the horseshoe bat (Rhinolophus sp) as its reservoir and the transmission is through droplets that contain viral load, mainly airway secretions such as coughing, sneezing and saliva, and/ or contaminated surfaces and subsequent contact with mucous membranes.'

According to Pan American Health Organization, 107,423,526 cases of COVID-19 and 2,360,280 deaths have been confirmed worldwide up to February 12, 2021. In Brazil, there were 10,195,160 confirmed cases and 555,460 deaths registered. ${ }^{2}$

Among the most prevalent symptoms of COVID-19 are fever, fatigue and dry cough. However, the patient may be asymptomatic or even present myalgia, dyspnea, rhinorrhea, headache, pharyngitis, diarrhea, hyporexia, hyposmia, ageusia, among other symptoms that progress progressively. ${ }^{3 \cdot 4}$

As it is a complex pathogen, it can lead to complications such as kidney or heart damage, secondary infections and even shock. In addition, mortality rates are directly related to age group, especially elderly people over 80 years old, and the presence of comorbidities such as chronic respiratory diseases, diabetes, heart disease and cancer. ${ }^{1,6}$

Although respiratory symptoms are the most commonly associated with COVID-19, headache represents the highest prevalence among neurological manifestations related to the infection, which may or may not be associated with the presence of fever ${ }^{6}$, often occurring in association with other symptoms such as anosmia, diarrhea, among others. ${ }^{7}$ Headache presents in approximately $11 \%$ to $34 \%$ of hospitalized patients due to COVID-19 and is reported by approximately $6 \%$ to $10 \%$ of symptomatic patients who did not require hospitalization during the period of disease activity. ${ }^{8}$

Regarding the characteristics of headache resulting from COVID-19, it is believed that it can have a rapid or insidious onset, being generally unresponsive to simple analgesics. In addition, it presents as a pulsatile pain, of moderate intensity, bilateral and in the temporoparietal, frontal or periorbital region. ${ }^{8}$

However, as the clinical picture of the disease is varied, headache can occur as an isolated symptom of COVID-19 and, being a common occurrence in everyday life, it ends up being ignored by some patients, but in most cases, it occurs in association with other symptoms. ${ }^{7}$ Among them are hyposmia/anosmia and with hypogeusia/ageusia, and patients who reported olfactory and/or taste symptoms had a higher frequency of headache than patients without these symptoms. ${ }^{9}$

Another study carried out in Zhejiang Province, China, showed that patients with nausea, vomiting or diarrhea experienced headache more frequently than patients without gastrointestinal symptoms. ${ }^{10}$

In addition, headache is also related to a better prognosis for patients, as it has been shown that there is a decrease in the duration of the disease in these individuals, in addition to the serum levels of interleukin-6 (IL-6), a proinflammatory cytokine. smaller and more stable during hospitalization. ${ }^{11}$

Therefore, due to the variety of possible symptoms of this disease and the impact of headache on these patients, this study will carry out a systematic review with the aim of evaluating the clinical characteristics and symptoms associated with headache in the acute phase of infection by COVID-19.

\section{Methodology}

A systematic literature review was performed based on the identification of published articles on the clinical characteristics and symptoms associated with headache in patients diagnosed with acute infection by COVID-19.

The search for the materials was carried out from February to August 2021, through a systematic review using the databases PubMed, Biomed Central, Biblioteca Virtual em Saúde (BVS), LILACS e Cochrane.

The keywords used in the search for the articles were "COVID-19" AND "headache". The selected publications were read in full, and systematized based on their main 
characteristics.

Were included articles reporting the presentation of headache and the acute symptoms associated with it in patients diagnosed with COVID-19 during the period from December 2019 to August 2021. Articles reporting changes in headache patterns in post-infection patients by coronavirus, or articles that reported only epidemiological characteristics or therapeutic approach, as well as articles that were published before December 2019 or case series with less than 10 patients were exclude.

Thus, 14 articles were analyzed, of which 7 were selected and briefly described in Table 1. A tabulation of the data found was formulated. Thus, the items were described: title, authors; year; description of the sample and synthesis of the results. From this, a descriptive and qualitative analysis of the bibliographic sample was performed, following the critical discussion of the content

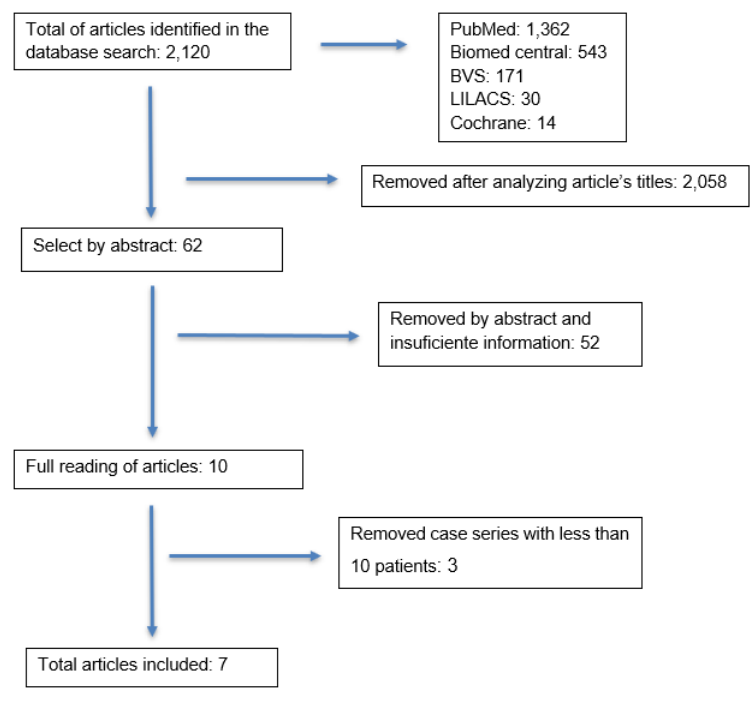

\section{Results}

\section{Data and results are in table 1}

\section{Discussion}

After the appearance of several cases of atypical pneumonia in China at the end of 2019, and from clinical and laboratory investigations, it was discovered that the viral etiology of the new disease called COVID-19 would be due to acute respiratory coronavirus syndrome 2 (SARS-CoV-2), which is responsible for the current pandemic. ${ }^{3}$
The pathology in question has a high potential for contagion through mucous secretions and contaminated fomites, presents with a wide range of clinical manifestations, which may involve not only the respiratory system, but also the gastrointestinal, hepatic and neurological systems. ${ }^{12}$

Considering the frequency of headache as a symptom reported in patients infected with SARS-CoV-2, there was a need to understand other manifestations associated with this complaint. Thus, the studies shown in Table 1 corroborate the association of these symptoms.

The cross-sectional study of Madgy et al. ${ }^{4}$ showed that headache in the studied patients was characterized by diffuse pressure pain $(52.9 \%)$, with moderate intensity and frequency of 7 days a week. It also suggested that the frequency of this symptom was related to a previous history of headache, severity of the infection (mild or moderate), dehydration and comorbidity, with relevant statistical significance $(p<0.05)$. In the female sex, the presence of fever and dehydration were associated with predictors of pain intensity. ${ }^{13}$

The cross-sectional study by Membrilla et al. ${ }^{14}$ demonstrates that among patients seen in the emergency room, with a confirmed diagnosis of COVID-19 and who complained of headache, $38.9 \%$ also had anosmia. Headache was characterized as moderate intensity, bilateral, frontal or holocranial. Also in this study, fever was identified as a predictor in $39.4 \%$ of those patients who had headache and a propensity for prostration, photophobia and phonophobia. Other factors that showed statistical significance $(p<0.05)$ associated with the presence of headache were a history of migraine, odynophagia, myalgia, anosmia and comorbidities such as systemic arterial hypertension, dyslipidemia and liver disease. ${ }^{14}$

The case study by Toptan et al. ${ }^{7}$ had thirteen participants, who had headache as the main complaint and who were later diagnosed with COVID-19. The headache was mostly described as holocranial with focus on the frontal and lateral areas bilaterally, throbbing/pulsating and/or with moderate to severe pressure sensation, more frequently associated with photophobia and/or phonophobia in nine of the patients, two of them had anosmia associated. Headache was also accompanied by gastrointestinal tract symptoms in five participants. And only one had osmophobia associated with the disease. ${ }^{7}$

The cross-sectional study by Rocha-Filho and Magalhães 9 showed that $64.4 \%$ of the participants had headache, the most common presentation being bilateral (94\%), with severe intensity (53\%). Patients with previous migraine had a migraine 
Table 1. Description of studies with characteristics and symptoms associated with headache in patients in the acute phase of infection by COVID-19.

\begin{tabular}{|c|c|c|c|c|}
\hline Authors & Local & Study period & Sample size & Results \\
\hline Magdy et al. ${ }^{4}$ & Cairo e Beni-Suef & $\begin{array}{l}\text { April to } \\
\text { June of } \\
2020\end{array}$ & 172 & $\begin{array}{c}52.9 \% \text { had diffuse headache, with frequency and intensity } \\
\text { predictors of fever }(69.8 \%) \text {, dehydration (64.5\%) and } \\
\text { presence of comorbidities (19.8\%). }\end{array}$ \\
\hline Membrilla $^{14}$ & Madrid & $\begin{array}{l}\text { March to } \\
\text { April of } \\
2020\end{array}$ & 145 & $\begin{array}{l}68.3 \% \text { of the patients reported headache. Among these, a } \\
\text { propensity to prostration }(41.4 \%) \text {, photophobia }(29.3 \%) \text { and } \\
\text { phonophobia }(27.3 \%) \text { were identified. In addition, of } 45 \\
\text { confirmed patients, } 28 \text { had anosmia. Fever was identified as a } \\
\text { precursor to headache in } 39.4 \% \text { of patients. }\end{array}$ \\
\hline Caronna et al. ${ }^{11}$ & $\begin{array}{c}\text { Barcelona (Hospital } \\
\text { Vall d'Hebro) }\end{array}$ & $\begin{array}{l}\text { March to } \\
\text { April of } \\
2020\end{array}$ & 130 & $\begin{array}{l}74.6 \% \text { had headache, and this group with headache suffered } \\
\text { more anosmia/ageusia ( } 54.6 \% \text { vs } 18.2 \%) \text { when compared } \\
\text { to the group without headache. And the headache group } \\
\text { still had a shorter presentation of the disease }(23.9 \pm 11.6 \text { vs. } \\
31.2 \pm 12.0 \text { days). }\end{array}$ \\
\hline $\begin{array}{c}\text { Rocha-Filho and } \\
\text { Magalhães } 9\end{array}$ & $\begin{array}{l}\text { Pernambuco (Hospital } \\
\text { Universitário Oswaldo } \\
\text { Cruz) }\end{array}$ & $\begin{array}{l}\text { May to June } \\
\text { of } 2020\end{array}$ & 73 & $\begin{array}{l}47 \text { of these (64.4\%) had headache, which was associated } \\
\text { with anosmia in } 28 \text { patients }(38.4 \%) \text { and with ageusia in } 29 \\
\text { patients }(39.7 \%) \text {. Individuals with hyposmia/anosmia and/ } \\
\text { or hypoageusia/ageusia had more headache than those } \\
\text { without these symptoms (OR: } 5.39 ; 95 \% \mathrm{Cl} \text { : } 1.66-17.45 \\
\text { logistic regression). Headache accompanied by photophobia } \\
\text { was more prevalent in patients with anosmia and ageusia } \\
\qquad(\mathrm{p}<0.05)\end{array}$ \\
\hline Toptan et al. ${ }^{7}$ & $\begin{array}{l}\text { Hospital Universitário } \\
\text { de Gazi, Ankara, } \\
\text { Turquia }\end{array}$ & $\begin{array}{l}\text { April to } \\
\text { May of } \\
2020\end{array}$ & 13 & $\begin{array}{c}\text { The most frequent associated symptoms were photophobia } \\
\text { and/or phonophobia. } \\
\text { Headache was associated with gastrointestinal tract symptoms } \\
\text { (diarrhea, loss of appetite, or weight loss) in five patients, and } \\
\text { patients had anosmia associated with phonophobia and/or } \\
\text { photophobia. }\end{array}$ \\
\hline Anjos de Paula ${ }^{13}$ & $\begin{array}{l}\text { Hospital Universitário } \\
\text { Walter Cantído } \\
\text { (HUWC), Hospital } \\
\text { Geral de Fortaleza } \\
\text { (HGF), e Hospital } \\
\text { São José de Doenças } \\
\text { Infecciosas (HSJ) }\end{array}$ & $\begin{array}{l}\text { May to July } \\
\text { of } 2020\end{array}$ & 108 & $\begin{array}{c}27.7 \% \text { had headache, and most suffered from associated } \\
\text { symptoms (58.3\%) including anosmia ( } 33 \%) \text {, irritability } \\
(16.6 \%) \text {, nausea, dizziness, allodynia and changes in } \\
\text { concentration (8.3\%) and vomiting, photophobia and } \\
\text { adynamia (4.1\%). }\end{array}$ \\
\hline Trigo et al. ${ }^{15}$ & Valladolid, Espanha & $\begin{array}{l}\text { March to } \\
\text { April of } \\
2020\end{array}$ & 576 & $\begin{array}{c}\text { Main associated symptoms were anosmia (46.7\%), arthralgia } \\
\text { (131\%), cough }(82.5 \%) \text {, dizziness }(13.9 \%) \text {, myalgia }(40.1 \%) \text {, } \\
\text { asthenia (51.1\%), chest pain }(24.1 \%) \text { and fever }(88.3 \%) \text {. }\end{array}$ \\
\hline
\end{tabular}

phenotype more often $(p<0.05)$. Headache was associated with ageusia in $39.7 \%$ and with anosmia in $38.4 \%$ of cases. Patients with hyposmia/anosmia and/or hypoageusia/ ageusia were approximately five times more likely to have headache than those who did not present these symptoms $(p=0.024)$. And when comparing the group with headache with anosmia and ageusia and the group with headache without these symptoms, it was shown that the association with phonophobia was greater in the group with anosmia and ageusia $(p<0.05) .{ }^{9}$

The prospective study by Caronna et al. ${ }^{11}$ described a comparative analysis between the group of patients who experienced headache during the infecction and those who did not. Of the total group, $74.6 \%$ had headache, in comparison these patients had more anosmia/ageusia $(p<0.0001)$, had a lower clinical course of disease $(p=0.028)$, as well as had lower levels of interleukin- 6 in the emergency room $(p=0.036)$ and were more stable during hospitalization. ${ }^{11}$

A multicenter retrospective study, carried out in the hospitals:
Hospital Universitário Walter Cantído (HUWC), General Hospital of Fortaleza (HGF), and Hospital São José for Infectious Diseases (HSJ), with 108 patients diagnosed with COVID-19, reports that $27.7 \%$ of these patients presented headache, therefore it was the second most prevalent neurological symptom. $58.3 \%$ of these patients had symptoms associated with headache, including anosmia $(33 \%)$, irritability $(16.6 \%)$, nausea, vertigo, allodynia and concentration changes $(8.3 \%)$ and vomiting, photophobia and adynamia (4.1\%). There was also an association with a greater presence of fever in these patients $(p=0.0028)$. The majority $(70.8 \%)$ reported worsening of the headache with physical activity or coughing. ${ }^{13}$

The retrospective cohort study carried out in Spain with 576 patients, showed that headache was more frequently associated with anosmia, arthralgia, cough, dizziness and myalgia. ${ }^{15}$ Regarding the presence of this set of symptoms, they found a lower probability of death due to premature search for the emergency room compared to those patients without headache. ${ }^{15}$ 
The main limitation found in this study was the heterogeneity of the studies and the low methodological quality of the studies published so far, also in part, because it is a recently discovered disease and there are still unknowns about COVID-19.

\section{Conclusion}

The systematic review carried out demonstrates that the headache manifested in COVID-19 is, in most cases, holocranial, with a moderate to severe pain intensity. Furthermore, it is suggestive that it is associated with signs and symptoms such as fever, hyposmia or anosmia, ageusia and phonophobia. In addition, some conditions are predictors of more intense headache attacks, such as a previous diagnosis of migraine, the intensity of the coronavirus infection, dehydration and the presence of comorbidities.

Conflict of Interest: The authors declare no conflict of interest. Author contribution: The authors contributed equally to the manuscript.

Vitória Rodrigues Salomão

https://orcid.org/0000-0002-8902-7378

Anna Júlia Romão Baccarin

hitps://orcid.org/0000-0002-6223-2929

Thaís Yayoi Okido

https://orcid.org/0000-0002-2507-575X

\section{References}

1. Xavier AR, Silva JS, Almeida JPC, Conceição JFF, Lacerda GS and Kanaan S. COVID-19: clinical and laboratory manifestations in novel coronavirus infection. J Bras Patol Med Lab 2020; 56(1-9 Doi:10.5935/16762444.20200049

2. Painel Coronavírus. 2021: https://covid.saude.gov. br/

3. WHO Director-General's remarks at the media briefing on 2019-nCoV on 11 February 2020. 2021:

4. Magdy R, Hussein M, Ragaie C, Abdel-Hamid HM, Khallaf A, Rizk HI and Dahshan A. Characteristics of headache attributed to COVID-19 infection and predictors of its frequency and intensity: $A$ cross sectional study. Cephalalgia 2020; 40(13):14221431 Doi: $10.1177 / 0333102420965140$

5. Wu Z and McGoogan JM. Characteristics of and Important Lessons From the Coronavirus Disease 2019 (COVID-19) Outbreak in China: Summary of a Report of 72314 Cases From the Chinese Center for Disease Control and Prevention. Jama 2020;
323(13):1239-1242 Doi:10.1001/jama.2020.2648

6. Uygun Ö, Ertaș M, Ekizoğlu E, Bolay H, Özge A, Kocasoy Orhan E, . . Baykan B. Headache characteristics in COVID-19 pandemic-a survey study. J Headache Pain 2020; 21(1):121 Doi:10.1186/ s10194-020-01188-1

7. Toptan T, Aktan C, Bașarı A and Bolay H. Case Series of Headache Characteristics in COVID-19: Headache Can Be an Isolated Symptom. Headache 2020; 60(8):1788-1792 Doi:10.1111/head.13940

8. Bolay H, Gül A and Baykan B. COVID-19 is a Real Headache! Headache 2020; 60(7):1415-1421 Doi: $10.1111 /$ head. 13856

9. Rocha-Filho PAS and Magalhães JE. Headache associated with COVID-19: Frequency, characteristics and association with anosmia and ageusia. Cephalalgia 2020; 40(13):1443-1451 Doi: $10.1177 / 0333102420966770$

10. Jin $X$, Lian JS, Hu JH, Gao J, Zheng L, Zhang YM, . .Yang Y. Epidemiological, clinical and virological characteristics of $\mathbf{7 4}$ cases of coronavirus-infected disease 2019 (COVID-19) with gastrointestinal symptoms. Gut 2020; 69(6):1002-1009 Doi:10.1 136/gutjnl-2020-320926

11. Caronna E, Ballvé A, Llauradó A, Gallardo VJ, Ariton DM, Lallana S, . . Pozo-Rosich P. Headache: A striking prodromal and persistent symptom, predictive of COVID-19 clinical evolution. Cephalalgia 2020; 40(13):1410-1421 Doi: $10.1177 / 0333102420965157$

12. Umakanthan S, Sahu P, Ranade AV, Bukelo MM, Rao JS, Abrahao-Machado LF, ... Kv D. Origin, transmission, diagnosis and management of coronavirus disease 2019 (COVID-19). Postgrad Med J 2020; 96 (1 142 ):753758 Doi:10.1136/postgradmedj-2020-138234

13. Anjos Paula RC, Maria Frota Vasconcelos T, Costa FBS, Brito LA, Torres DM, Moura AEF, . . SobreiraNeto MA. Characterization of Headache in COVID-19: a Retrospective Multicenter Study. Mol Neurobiol 2021; 58(9):4487-4494 Doi:10.1007/s12035-02102430-w

14. Membrilla JA, de Lorenzo Í, Sastre Mand Díaz de Terán J. Headache as a Cardinal Symptom of Coronavirus Disease 2019: A Cross-Sectional Study. Headache 2020; 60(10):2176-2191 Doi:10.1111/head.13967

15. Trigo J, García-Azorín D, Planchuelo-Gómez Á, Martínez-Pías E, Talavera B, Hernández-Pérez I, . . .Guerrero Á L. Factors associated with the presence of headache in hospitalized COVID-19 patients and impact on prognosis: a retrospective cohort study. J Headache Pain 2020; 21(1):94 Doi:10.1186/ s10194-020-01165-8 